Poznańskie Studia Teologiczne 30(2016), s. 449-462.

doi: $10.14746 /$ pst.2016.30.22

Anna Zellma ${ }^{1}$

Uniwersytet Warmińsko-Mazurski w Olsztynie

\title{
(Nie)zwykłe znaczenie pedagogiki dialogu w teorii nauczania religii
}

Współczesne obszary aktywności nauczyciela religii w polskiej szkole są wielorakie. Wyznacza je m.in. podstawowy cel nauczania i wychowania w wierze dzieci i młodzieży, sytuacja egzystencjalna adresatów oraz myślenie pedagogiczne nauczycieli religii i katechetyków. Również zmiany zachodzące w różnych obszarach życia społecznego, a zwłaszcza w edukacji szkolnej wpływają na jakość postrzegania zadań dydaktyczno-wychowawczych nauczyciela religii w szkole ${ }^{2}$. Coraz większą wagę przywiązuje się do kompetencji pedagogicznych, które znajdują ukonkretnienie $\mathrm{w}$ myśleniu i działaniu osób odpowiedzialnych za nauczanie religii ${ }^{3}$. Stąd też obszar badań prowadzonych w Polsce przez współczesnych katechetyków wykracza poza tradycyjne rozumienie procesów nauczania religii w szkole 4 . Odczytując „,znaki czasu”, badacze podejmują problematykę pedagogiczną, która może wzmocnić jakość aktywności dydaktyczno-wychowawczej nauczyciela religii $\mathrm{w}$ środowisku szkolnym ${ }^{5}$. Za istotne uznają nie tylko aspekty teoretyczne, ale także praktyczne różnych koncepcji nauczania i wychowania ${ }^{6}$. Do nich zaliczają m.in. procesy porozumiewania się podmiotów uczestniczących

\footnotetext{
${ }^{1}$ Anna Zellma - profesor doktor habilitowany nauk teologicznych; kierownik Katedry Teologii Pastoralnej i Katechetyki na Wydziale Teologii Uniwersytetu Warmińsko-Mazurskiego w Olsztynie; członek zarządu Stowarzyszenia Katechetyków Polskich; członek The European Equipe for Catechesis (EEC) i Polskiego Towarzystwa Teologicznego, konsultor Komisji Wychowania Katolickiego Konferencji Episkopatu Polski. Zainteresowania badawcze: katecheza młodzieży, dydaktyka nauczania religii, profesjonalny rozwój nauczyciela religii, pedeutologia, dydaktyka ogólna, badania empiryczne, pedagogika chrześcijańska, wychowanie prorodzinne.

${ }^{2}$ Szerzej o tym zob. np. w: E. Bednarz, Nauczyciel katecheta wobec wspótczesnych wyzwań dydaktycznych $i$ wychowawczych, „Rocznik Teologiczny” 5(2013) z. 1-2, s. 273-287.

${ }^{3}$ Zob. np. J. Szpet, Kompetentny katecheta, „Katecheza, Rodzina, Parafia i Szkoła” 1(2003), s. 9-14; A. Zellma, Kompetencje nauczyciela religii jako perspektywa efektywności edukacyjnej, „Katecheta” 53(2009) nr 6, s. 3-12.

${ }^{4}$ Do takich wniosków prowadzi m.in. analiza opisu bibliograficznego publikacji opracowanego przez R. Czekalskiego, w: Bibliografia katechetyczna 2001-2010, Warszawa 2012.

${ }^{5}$ Zob. tamże.

${ }^{6}$ Tamże.
} 
w realizacji nauczania religii w szkole, wartość dialogu edukacyjnego oraz kształtowanie postawy dialogu wśród uczestników lekcji religii ${ }^{7}$.

Wobec powyższego uzasadnione wydaje się zwrócenie uwagi na znaczenie pedagogiki dialogu $\mathrm{w}$ różnych obszarach nauczania religii $\mathrm{w}$ szkole. Podjęte w artykule zagadnienie badawcze koncentruje się wokół poszukiwania odpowiedzi na pytanie: Jakie znaczenie ma pedagogika dialogu dla teorii nauczania religii? Czy jest ona jednym z podstawowych komponentów w dydaktyce katechezy, niczym niewyróżniającym się, od dawna obecnym w teorii, stanowiącym jej integralną część, i czy spełnia zwyczajne funkcje? A może przeciwnie, znaczenie pedagogiki dialogu dla teorii nauczania religii nie jest typowe, lecz wyjątkowe, wyznacza nowe, dotąd nieobecne lub marginalizowane, ale ważne dla praktyki, obszary badawcze, wymaga szczególnego wyakcentowania, a w przyszłości nawet wyodrębnienia katechetyki dialogu? Poszukiwanie odpowiedzi na tak postawione pytania wymaga najpierw syntetycznego wprowadzenia w problematykę. W tym kontekście zostaną opisane elementy pedagogiki dialogu, które wskazują na jej rolę w nauczaniu religii i w znacznym stopniu warunkują jakość pracy nauczyciela religii. Zwróci się też uwagę na sposoby prowadzenia dialogu w nauczaniu religii, które zostały opisane w literaturze. Wszystko to pozwoli określić kierunek dalszych, szczegółowych badań dotyczących znaczenia pedagogiki dialogu w nauczaniu religii.

\section{Pedagogika dialogu - uwagi wstępne}

$\mathrm{W}$ ostatnich latach pojęcie dialog często pojawia się w pracach polskich pedagogów ${ }^{8}$. Badacze analizują go w różnym kontekście, zwracając przy tym uwagę na wielowątkowość i zróżnicowanie ${ }^{9}$. Zgodnie twierdzą, że dominujący dotychczas monolog w edukacji szkolnej okazał się mało skuteczny i niedostosowany do mentalności adresatów ${ }^{10}$. Szanse na przezwyciężenie kryzysu edukacji upatrują

7 Zob. np. R. Czekalski, Katecheza komunikacja wiary. Studium z katechetyki fundamentalnej, Płock 2006; M. Gogolik, ,,Nauczycielu dobry... ” Paradygmat nauczyciela religii w świetle rozmowy Jezusa Chrystusa z bogatym młodzieńcem, Poznań 2012; G. Łuszczak, Od teorii stopni formalnych do teorii komunikacji i dialogu w dydaktyce szkolnej i katechetycznej, Kraków 2012; Dia$\log w$ katechezie, red. S. Kulpaczyński, Lublin 1998.

${ }^{8}$ Zob. np. A. Al-Khamisy, Edukacja właczajaca edukacja dialogu: w poszukiwaniu modelu edukacji dla ucznia ze specjalnymi potrzebami edukacyjnymi, Warszawa 2013; Pedagogika dialogu: dialog w teorii i praktyce edukacyjnej, red. E. Dą̧rowy, D. Jankowska, Warszawa 2009; Pedagogika dialogu: wokół pedagogii Janusza Korczaka, red. D. Jankowska, Warszawa 2014; Wychowanie do dialogu: w poszukiwaniu modeli budowania relacji międzyludzkich, red. K. Jaworska, K. Wawrzynów, G. Sokołowski, Wrocław 2015; M. Śnieżyński, Sztuka dialogu, Kraków 2008; Przestrzeń i czas dialogu w edukacji, red. D. Waloszek, Kraków 2011.

${ }^{9}$ Tamże.

${ }^{10}$ Tamże. 
w myśleniu dialogicznym nauczycieli ${ }^{11}$. Stąd też konsekwentnie traktują dialog zarówno jako narzędzie doskonalenia edukacji, jak też jako wyznacznik dobrej zmiany w projektowaniu i realizacji założeń programowych ${ }^{12}$.

Zasadne wydaje się również odwołanie pedagogów do filozofii ${ }^{13}$. Dialog ma bowiem filozoficzne podstawy, co w pedagogice przyjmuje się jako pewną oczywistość ${ }^{14}$. W związku z tym pedagodzy za ważne uznają dialogiki Sokratesa i Platona oraz refleksję naukową klasyków filozofii dialogu (np. M. Bubera, F. Rosenzweiga, E. Lévinasa) ${ }^{15}$. Coraz częściej też zwracają uwagę na propagowany w Polsce przez ks. Janusza Tarnowskiego tzw. personalizm dialogiczny, który zajmuje ważne miejsce $\mathrm{w}$ pedagogice dialogu ${ }^{16}$. Znamienne jest, że właśnie ten pedagog odegrał ważną rolę w rozwoju pedagogiki dialogu na gruncie polskim. Ksiądz Janusz Tarnowski, dążąc do wypracowania podstawowych wyznaczników wychowania jako spotkania opartego na relacji „Ja” - „Ty” i wynikających stąd konsekwencji wychowawczych, przyczynił się do rozwoju pedagogiki dialogu rozumianej jako nauka o wychowaniu, w którym ważne miejsce zajmuje „bycie w relacji [...] do świata rzeczy i ludzi” ${ }^{17}$. Konsekwentnie zwracał uwagę na proces stawania się w pełni człowiekiem i integralnego rozwoju, jaki ma miejsce pod wpływem kontaktów interpersonalnych ${ }^{18}$. Słusznie za istotną uznał relację „Ja-Ty”, której „podstawową kategorią jest dialog” o wyraźnym wymiarze egzystencjalnym ${ }^{19}$. Tak rozumiany , dialog nie ma jedynie na celu do-

${ }^{11}$ Zob. np. Kreatorzy edukacyjnego dialogu, red. A. Karpińska, Białystok 2002; E. Murawska, Od monologu do dialogu - refleksje o (nie)porozumieniu między nauczycielem a uczniem, „Edukacja” 2005 nr 2, s. 51-56; M. Śnieżyński, Droga do dialogu edukacyjnego, „Świat i Słowo” 2008 nr 2, s. 241-257. 2006.

${ }^{12}$ Zob. np. tamże; J. Kujawiński, Szkoła dialogu i samodzielnego uczenia się uczniów, Poznań

${ }^{13}$ Zob. np. B. Milerski, Pedagogika dialogu: filozoficzne inspiracje i perspektywy, „Paedagogia Christiana" 1/21(2008), s. 36-42; M. Śnieżyński, Od monologu do dialogu edukacyjnego, w: Wychowanie na rozdrożu. Personalistyczna filozofia wychowania, red. F. Adamski, Kraków 1999, s. 117-128; S.C. Michałowski, Spotkanie jako metoda bycia w pedagogice personalistycznej, w: Wychowanie na rozdrożu. Personalistyczna filozofia wychowania, s. 129-143.

${ }^{14}$ B. Milerski, Pedagogika dialogu: filozoficzne inspiracje i perspektywy, s. 36 i nn.

${ }^{15}$ Szerzej o tym zob. np. w: tamże.

${ }^{16}$ Zob. np. tamże; T. Gadacz, Wychowanie jako spotkanie osób, w: Człowiek - wychowanie kultura, red. F. Adamski, Kraków 1993, s. 107-113; U. Walijewska, Dialog w edukacji wczesnoszkolnej, http://www.eid.edu.pl/archiwum/1999,97/czerwiec,150/dialog_w_edukacji_wczesnoszkol nej,865.html [dostęp: 23.04.2016].

${ }^{17}$ B. Milerski, Pedagogika dialogu: filozoficzne inspiracje i perspektywy, s. 37; por. J. Tarnowski, Pedagogika dialogu, w: Edukacja alternatywna. Dylematy teorii i praktyki, red. B. Śliwerski, Kraków 1992, s. 119-129.

${ }^{18}$ J. Tarnowski, Dialog podstawowa kategoriq personalistycznej filozofii wychowania, w: Wychowanie na rozdrożu. Personalistyczna filozofia wychowania, s. 185-186.

${ }_{19}$ Tenże, Jak wychowywać?, Warszawa 1993, s. 116-118 i nn; zob. więcej o tym np. w: B. Milerski, Pedagogika dialogu: filozoficzne inspiracje i perspektywy, s. 38. 
chodzenia do jakiejś wspólnej wiedzy przedmiotowej (aspekt metodyczny) [...]". Przeciwnie, wiąże się wprost ze spotkaniem osób, które „otwierają się na siebie wzajemnie, ujawniając nie tylko własne przekonania i uznawane wartości, lecz również «będąc dla siebie nawzajem»"20. Autentyczny dialog - jak słusznie twierdził ks. J. Tarnowski - odgrywa ważną rolę w procesie wychowania ${ }^{21}$. Przyczynia się bowiem do wzajemnego, ubogacającego wewnętrznie spotkania osób, a przez to do przemiany życia uczestników wychowania oraz lepszego poznania siebie $^{22}$. Niewątpliwie wszystko to ma szczególne znaczenie w procesie wspierania wychowanków w urzeczywistnianiu swojego człowieczeństwa ${ }^{23}$. Zasługuje także na uwagę nie tylko $\mathrm{w}$ teorii nauczania religii, ale również $\mathrm{w}$ praktyce.

Wprowadzając w problematykę pedagogiki dialogu, należy też zwrócić uwagę na propozycje Joanny Rutkowiak ${ }^{24}$. Autorka wiele uwagi poświęca zagadnieniom dialogu edukacyjnego ujmowanym z perspektywy dydaktyki ogólnej i pedeutologii. Posługuje się terminem „dialog bez arbitra" ${ }^{25}$. Kategoria ta wskazuje na równość partnerów. W „dialogu bez arbitra” pozycja uczestników nie jest uzależniona od wieku, wiedzy, doświadczenia, prestiżu ${ }^{26}$. Przeciwnie, ważną funkcję spełniają różne punkty widzenia, doświadczenia, odmienności uczestników dialogu. Każdy z nich bowiem wnosi swój własny wkład i przyczynia się do konstruowania nowych twórczych rozwiązań i pomysłów ${ }^{27}$. Stąd też istotą „dialogu bez arbitra" jest traktowanie wszystkich głosów i pomysłów za znaczące dla poszukiwania konstruktywnych rozwiązań (np. podczas zajęć edukacyjnych, debat, spotkań) ${ }^{28}$.

Kategoria „dialogu edukacyjnego" zajmuje też ważne miejsce w opracowaniach Mariana Śnieżyńskiego ${ }^{29}$. Autor wiele uwagi poświęca werbalnej wymianie pomiędzy uczestnikami zajęć edukacyjnych, a zwłaszcza pomiędzy nauczycielem i uczniem ${ }^{30}$. Słusznie wszystkich uczestników procesów nauczania-uczenia się i wychowania uznaje za podmioty dialogu ${ }^{31}$. W tym kontekście analizuje interakcje zachodzące między uczniem i nauczycielem oraz metody kształcenia

${ }^{20}$ B. Milerski, Pedagogika dialogu: filozoficzne inspiracje i perspektywy, s. 38.

${ }^{21}$ J. Tarnowski, Dialog podstawowa kategoria personalistycznej filozofii wychowania, s. 185-186.

${ }^{22}$ B. Milerski, Pedagogika dialogu: filozoficzne inspiracje i perspektywy, s. 38.

${ }^{23}$ Tamże.

${ }^{24}$ Pytanie, dialog, wychowanie, red. J. Rutkowiak, Warszawa 1992.

${ }^{25}$ Taż, „Dialog bez arbitra” jako koncepcja relacji między nauczycielem a uczniem, „Ruch Pedagogiczny" 1984 nr 5-6, s. 120-128.

${ }^{26}$ Tamże.

27 Tamże.

${ }^{28}$ Szerzej o tym zob. np. tamże; J. Rutkowiak, Dialog pedagogiczny jako warunek możliwości rozumienia, „Ruch Pedagogiczny” 1989 nr 5-6, s. 58-51; taż, Stosowanie teorii pedagogicznej w praktyce a dialog edukacyjny, „Kwartalnik Pedagogiczny” 1986 nr 1, s. 47-58.

${ }^{29}$ M. Śnieżyński, Sztuka dialogu, s. 12 i nn; tenże, Dialog edukacyjny, s. 7 i nn.

${ }^{30}$ Tamże.

${ }^{31}$ Tamże. 
oparte na dialogu edukacyjnym. Obok treściowej zawartości dialogu edukacyjnego M. Śnieżyński opisuje jego cele i funkcje, do których zalicza m.in. pozyskiwanie wiedzy, rozwiązywanie problemów, wzajemne zrozumienie, wypracowanie wspólnego stanowiska ${ }^{32}$. To właśnie autentyczny dialog edukacyjny odgrywa ważną rolę w nauczaniu i wychowaniu integralnym ${ }^{33}$.

Wyżej opisane obszary treściowe pedagogiki dialogu zasługują na szczególną uwagę $w$ aktywności edukacyjnej nauczycieli religii. Wymagają jednak teoretycznych podstaw, wypracowanych przez katechetyków. Specyfika nauczania religii $\mathrm{w}$ znacznym stopniu określa bowiem znaczenie propozycji z obszaru pedagogiki dialogu w teorii i praktyce.

\section{Rola pedagogiki dialogu w nauczaniu religii}

Analizując różne opracowania polskich katechetyków ${ }^{34}$, można dostrzec wiele ujęć i interpretacji kategorii z zakresu pedagogiki dialogu. Często występują one pośrednio. Dominuje przy tym powiązanie problematyki dialogu z wychowaniem ekumenicznym ${ }^{35}$. Słusznie autentyczny dialog postrzegany jest jako narzędzie zbliżenia do siebie wyznawców religii chrześcijańskich, poszukiwania wspólnych korzeni, kształtowania postawy otwartości i tolerancji oraz współdziałania na rzecz budowania pokoju w świecie ${ }^{36}$.

W teorii nauczania religii brakuje jednak bezpośredniego odniesienia do pedagogiki dialogu w edukacji religijnej dzieci i młodzieży. Analizowane są szczegółowe kwestie, które dotyczą różnych obszarów dialogu w nauczaniu religii ${ }^{37}$. Wiele uwagi poświęca się m.in. interakcji między nauczycielem religii a uczniem, w toku której ma miejsce nie tylko kontakt słowny, rozmowa, ale także dzielenie się wartościami, stawianie pytań egzystencjalnych i poszukiwanie na nie odpo-

32 Tamże.

33 Tamże.

${ }^{34}$ Zob. np. J. Bagrowicz, Towarzyszyć wzrastaniu. Z dyskusji o metodach i środkach edukacji religijnej młodzieży, Toruń 2006; R. Chałupniak, J. Kostorz, Wybrane zagadnienia z katechetyki, Opole 2002; R. Chałupniak, Asertywność i komunikacja katechety - w kierunku społecznej formacji katechetów, w: Dzisiejszy katecheta. Stan aktualny i wyzwania, red. J. Stala, Kraków 2002 , s. 241-256; P. Studnicki, Dialog edukacyjny w nauczaniu katechetycznym. Teoria a szkolna rzeczywistość, Kraków 2010; J. Szpet, Dydaktyka katechezy, Poznań 1999; B. Twardzicki, Katechetyka formalna w stużbie wiary, Przemyśl 2001.

${ }^{35}$ Zob. np. J. Kostorz, Ekumeniczny wymiar posoborowej katechezy w Polsce, Opole 2007.

36 Tamże.

${ }^{37}$ Zob. np. A. Bałoniak, Od werbalizmu do komunikacji: refleksja nad środkami dydaktycznymi w procesie nauczania, „Katecheta” 56(2012) nr 4, s. 67-72; S. Łabendowicz, Rozmowa w katechezie, „Zeszyty Formacji Katechetów” 8(2008) nr 1, s. 60-62; P. Studnicki, Dialog edukacyjny w nauczaniu katechetycznym. Teoria a szkolna rzeczywistość, s. 13 i nn; J. Stala, E. Osewska, Dyskutować, ale jak? „Tarnowskie Studia Teologiczne” 28(2009) z. 1, s. 39-50; Twardzicki, Katechetyka formalna $w$ stuzbie wiary, s. 355-359, 415-424. 
wiedzi, uważne i cierpliwe słuchanie, współpraca ${ }^{38}$. Za ważną uznaje się osobowość nauczyciela religii, jego postawę i odpowiednie zachowanie ${ }^{39}$. Na tym tle wielokrotnie podejmowane są kwestie dotyczące języka w katechezie, zasady podmiotowości oraz komunikowania się nauczyciela $\mathrm{z}$ uczniami opartego na współpracy ${ }^{40}$. To świadczy o dowartościowaniu propozycji, które zostały wypracowane w ramach pedagogiki dialogu.

Obok wyżej wymienionych kwestii w teorii nauczania religii wiele uwagi poświęca się zagadnieniom z zakresu dydaktyki dialogu, przez którą najogólniej rozumie się jeden z działów dydaktyki, zajmujący się badaniem procesów nauczania-uczenia się ze szczególnym uwzględnieniem aktywnego udziału uczestników zajęć edukacyjnych w wymianie myśli, stanowisk, poglądów, opinii, rozwiązywaniu problemów przy pełnym poszanowaniu podmiotowości każdej osoby oraz prawa do własnych poglądó $\mathrm{w}^{41}$. Tak określone zagadnienia wpisują się w kategorię dialogu edukacyjnego, a więc odnoszą się do szczegółowego zagadnienia z zakresu pedagogiki dialogu. Można zatem stwierdzić, że w teorii nauczania religii dowartościowany został jeden z obszarów pedagogiki dialogu.

Ponadto na tle szczegółowych zagadnień z zakresu dydaktyki dialogu w pracach badawczych katechetyków pojawiają się kwestie, które integralnie wiążą się z pedagogiką dialogu. Zwykle dotyczą one aktywnego udziału uczestników lekcji religii (uczniów i nauczycieli religii) w procesach wzajemnego poznania się i zrozumienia świata, siebie $\mathrm{i}$ innych ${ }^{42}$. W powiązaniu $\mathrm{z}$ tymi zagadnieniami słusznie badacze zwracają uwage na dialog informacyjny ${ }^{43}$. Znajduje on ukonkretnienie we właściwej konstrukcji pytań i odpowiedzi, które stawia nie tylko nauczyciel, ale również uczniowie ${ }^{44}$.

Mając na uwadze propozycje pedagogów, katechetycy odwołują się również do powszechnie znanych, wyżej opisanych, stwierdzeń filozofów dialogu ${ }^{45}$.

${ }^{38}$ Zob. np. A. Zellma, Profesjonalny rozwój nauczyciela religii, Olsztyn 2013; B. Twardzicki, Katechetyka formalna $w$ stużbie wiary, s. 196 i nn.

${ }^{39}$ Zob. np. tamże.

${ }^{40}$ Zob. np. S. Łabendowicz, Metody dialogowe i sytuacyjne w katechezie, „Zeszyty Formacji Katechetów” 10(2010) nr 3, s. 68-76; K. Misiaszek, W poszukiwaniu charakteru języka w katechezie, „Studia Pastoralne” 2(2006), s. 95-103; J. Szpet, Dydaktyka katechezy, s. 113 i nn.

${ }^{41}$ Zob. np. M. Korgul, Dydaktyka dla katechetów, Świdnica 2007, s. 74 i nn; S. Labendowicz, Wybrane propozycje metod w katechezie, „Zeszyty Formacji Katechetów” 6(2006) nr 2, s. 73-76; J. Szpet, Dydaktyka katechezy, s. 101 i nn.

42 Tamże; S. Łabendowicz, Wybrane metody aktywizujace w katechezie, „Zeszyty Formacji Katechetów" 13(2013) nr 2, s. 85-90.

${ }^{43}$ Zob. np. M. Korgul, Dydaktyka dla katechetów, s. 235-242; J. Szpet, Dydaktyka katechezy, s. $170 \mathrm{i} \mathrm{nn}$.

${ }^{44}$ Tamże; S. Łabendowicz, Aktywizowanie uczniów poprzez zastosowanie pytań w katechezie, „Zeszyty Formacji Katechetów” 8(2008) nr 2, s. 78-82; M. Śnieżyński, Rola i znaczenie pytań na lekcjach religii, „Katecheta” 58(2014) nr 4, s. 4-10.

${ }^{45}$ Zob. np. J. Bagrowicz, Towarzyszyć wzrastaniu. Z dyskusji o metodach i środkach edukacji religijnej młodzieży, s. 114 -118, 230 i nn; R. Chałupniak, Asertywność i komunikacja katechety - 
Słusznie zwracają uwagę na filozoficzne podstawy i inspiracje pedagogiki dialo$\mathrm{gu}^{46}$. Tak ukierunkowane analizy mają istotne znaczenie dla integralnego wychowania w nauczaniu religii. Wzmacniają założenia teoretyczne aktywności wychowawczej, którą nauczyciel religii podejmuje w szkole. Pozwalają dostrzec wspólne elementy między wychowaniem ogólnym a wychowaniem chrześcijańskim oraz traktować je jako kategorie integralnie ze sobą powiązane i wzajemnie uzupełniające się. Na przykład: dla teorii i praktyki nauczania religii znacząca jest opisana przez Janusza Tarnowskiego kwestia „,spotkania Ja-Ty”, której podstawę stanowi autentyczny dialog. Odwołanie do tej kategorii w katechetyce wzbogaca różne aspekty analizowanej w teorii aktywności wychowawczej nauczyciela religii. Wskazuje też na znaczenie dialogu w zbliżeniu wszystkich uczestników lekcji religii do siebie, otwieraniu na siebie, wzajemnym poznaniu i zrozumieniu, negocjowaniu znaczeń i konstruowaniu wiedzy ${ }^{47}$. Co ważne, poprzez odwołanie do pedagogiki dialogu wzmocniona zostaje - o racje pedagogiczne - argumentacja teologiczna dotycząca m.in. godności każdego ucznia, wolności, odpowiedzialności, powołania do życia we wspólnocie ${ }^{48}$.

W teorii nauczania religii wyżej wymienione kwestie zostaja poszerzone o problematykę dialogu człowieka z Bogiem ${ }^{49}$. Takie podejście wydaje się uzasadnione. W perspektywie nauczania religii dialog człowieka z Bogiem, który dokonuje się na płaszczyźnie wiary, odgrywa ważną rolę wychowawczą. Pozwala bowiem człowiekowi nawiązać bezpośredni, osobowy kontakt z Bogiem, stawiać pytania i poszukiwać na nie odpowiedzi w świetle słowa Bożego i nauczania Kościoła, rozeznawać własne powołanie życiowe. Z czasem dialog z Bogiem może wzmocnić wiarę, zrodzić pokój serca, umocnić w powołaniu. Słusznie ten rodzaj dialogu katechetycy uznają za znaczący dla nauczania religii, wprost związany z celami katechetycznymi i specyfiką lekcji religii ${ }^{50}$. Niewątpliwie wiara jako obszar dialogu człowieka z Bogiem poszerza perspektywę pedagogiki dialogu. Pamiętając o powyższym, katechetycy za niezaprzeczalny uznają fakt, że dialog człowieka z Bogiem ma miejsce na modlitwie ${ }^{51}$. Spotykając się z Bogiem „twarzą w twarz, jak [...] z przyjacielem” (Wj 33,7-11), człowiek otwiera swoje

w kierunku społecznej formacji katechetów, s. 241-256; S. Łabendowicz, Wychowanie do dialogu w katechezie, „Zeszyty Formacji Katechetów” 12(2012) nr 1, s. 79-86; P. Studnicki, Dialog edukacyjny w nauczaniu katechetycznym. Teoria a szkolna rzeczywistość, s. 14 i nn.

46 Tamże.

${ }^{47}$ Tamże.

${ }^{48}$ Zob. np. J. Bagrowicz, Stawać się bardziej człowiekiem. Z podstaw edukacji religijnej, Toruń 2008, s. 38 i nn.

${ }^{49}$ Zob. np. S. Kulpaczyński, Dialog katechetów z Bogiem podstawa ich dialogu z katechizowanymi, w: Dialog w katechezie, s. 71-82; tenże, Jak uczyć modlitwy katechizowanych?, „Roczniki Teologiczne" 54(2007) z. 6, s. 157-173; S. Łabendowicz, Wychowanie do wspólnej modlitwy na katechezie, „Zeszyty Formacji Katechetów” 8(2008) nr 2, s. 73-77.

${ }^{50}$ Tamże.

${ }^{51}$ Tamże. 
serce na działanie Ducha Świętego, który uzdalnia go do dialogu z Bogiem o sobie samym, własnych ograniczeniach, słabościach, pragnieniach i potrzebach $^{52}$. Takie ujęcie zagadnień z zakresu pedagogiki dialogu świadczy nie tylko o właściwym rozumieniu dialogu człowieka z Bogiem, ale także wskazuje na szersza, istotną dla nauczania religii, perspektywę.

\section{Sposoby prowadzenia dialogu $\mathrm{w}$ nauczaniu religii}

Interesujące, a zarazem znaczące dla praktyki, są sposoby prowadzenia dialogu edukacyjnego. Katechetycy słusznie zwracają uwagę nie tylko na dialog jako metodę nauczania, ale także wychowania ${ }^{53}$. Ta pierwsza kwestia dominuje w metodyce nauczania religii ${ }^{54}$. Badacze wielokrotnie opisują różne rozwiązania metodyczne, które bazują na słownej (werbalnej) komunikacji ${ }^{55}$. Słusznie podkreślają, że metody oparte na dialogu mają na celu aktywizowanie uczniów w poszukiwaniu i odkrywaniu prawdy, stymulowanie ich twórczości oraz motywowanie do dzielenia się odmiennymi punktami widzenia i własnymi doświadczeniami $^{56}$. W związku z powyższym za ważne uznają zastosowanie podczas lekcji religii (zwłaszcza w gimnazjum i w szkołach ponadgimnazjalnych) różnych odmian i technik dyskusji ${ }^{57}$. Obok klasycznej dyskusji wymieniają m.in. dyskusję okragłego stołu, dyskusję punktowaną, dyskusję wielokrotna, dyskusję panelową, dyskusję kielecką, trzy kąty, sześć myślących kapeluszy, linię specjalną, puste krzesło, trybunał, drzewko decyzyjne, metaplan ${ }^{58}$. Słusznie zwracają też uwagę na dialog uczniów z tekstem i metodę ,akwarium”59. Każde z wyżej wymienionych rozwiązań metodycznych ma wiele walorów dydaktycznych i wychowawczych. Stymuluje uczniów do słownego lub pisemnego werbalizowania własnych opinii i przekonań w celu rozwiązywania określonego problemu oraz oceniania i wartościowania ${ }^{60}$. Sprzyja też konfrontacji przeciwstawnych poglą-

52 Tamże.

${ }^{53}$ Zob. np. J. Bagrowicz, Towarzyszyć wzrastaniu. Z dyskusji o metodach i środkach edukacji religijnej młodzieży, s. $114-118,230$ i nn; S. Łabendowicz, Wychowanie do dialogu w katechezie, „Zeszyty Formacji Katechetów” 12(2012) nr 1, s. 79-86; P. Studnicki, Dialog edukacyjny w nauczaniu katechetycznym. Teoria a szkolna rzeczywistość, s. 14 i nn.

${ }^{54}$ Zob. np. tamże; J. Szpet, Dydaktyka katechezy, s. 187, 194-199.

${ }^{55}$ Zob. np. tamże; M. Korgul, Dydaktyka dla katechetów, s. 133-200; S. Łabendowicz, Metody ukierunkowane na dialog, „Zeszyty Formacji Katechetów” 12(2012) nr 1, s. 86-90; tenże, Metody dialogowe i sytuacyjne na katechezie, „Zeszyty Formacji Katechetów” 10(2010) nr 3, s. 68-76; E. Osewska, Pluralizm metod stosowanych w katechezie, w: Dydaktyka katechezy, cz. II, red. J. Stala, Tarnów 2004, s. 157-299.

${ }^{56}$ Tamże.

${ }^{57}$ Tamże.

${ }^{58}$ Tamże.

${ }^{59}$ Tamże.

${ }^{60}$ Tamże. 
dów oraz motywuje do poszukiwania i odkrywania prawdy w toku wymiany myśli i negocjowania znaczeń. Dobrze zastosowane odmiany dyskusji pozwalają uczniom nie tylko poszerzyć zakres wiedzy, ale także lepiej zrozumieć problemy egzystencjalne $^{61}$. Co więcej, wspomagają w kształtowaniu poglądów i dzieleniu się doświadczeniem. Tak więc różne odmiany i techniki dialogu, jak trafnie zauważają katechetycy, obok funkcji dydaktycznej, pełnią również funkcję wychowawczą ${ }^{62}$. Przyczyniają się bowiem do kształtowania umiejętności i kompetencji społecznych. Wymagają jednak odpowiedniego rozplanowania aktywności uczniów podczas lekcji religii. Słusznie zatem w powiązaniu z odmianami i technikami dialogu katechetycy zwracają uwagę na pracę katechizowanych w małych grupach $^{63}$. Ta forma organizacji aktywności uczniów podczas lekcji religii pomaga im w głębszym rozumieniu problemów. Sprzyja też rozwijaniu umiejętności argumentowania własnego zdania, zajmowania samodzielnego stanowiska, poszanowania opinii innych i lepszego zrozumienia przekonań innych osób oraz własnych ${ }^{64}$. Wymaga jednak od nauczyciela religii odpowiednich kompetencji metodycznych i komunikacyjnych. To właśnie osoba prowadząca zajęcia dobiera sposoby prowadzenia dialogu edukacyjnego. Pamiętając o istocie dialogu, zobowiązana jest rezygnować z pozornych rozwiązań takich, jak np. pogadanka (wstępna, utrwalająca, heurystyczna) i rozmowa kierowana ${ }^{65}$. Wymienione metody polegają na stawianiu pytań i udzielaniu poprawnych odpowiedzi, które zazwyczaj nauczyciel religii zna. W perspektywie założeń pedagogiki dialogu postrzeganie pogadanki i rozmowy kierowanej jako metod, które aktywizuja uczniów do dialogu, wydaje się niczym nieuzasadnione. Nie ma tu miejsca na wymianę zdań między rozmówcami oraz prezentowanie odmiennych punktów widzenia i różnych opinii ${ }^{66}$. Do głosu dochodzą jedynie różni rozmówcy (np. kilku uczniów odpowiada na pytania stawiane przez nauczyciela religii), którzy udzielają poprawnych, oczekiwanych przez nauczyciela religii, odpowiedzi. W mówienie angażują się różni uczniowie, „ale znaczenia, do których mają dojść, są z góry ustalone" ${ }^{67}$. Stąd też zastosowanie pogadanki i rozmowy kiero-

61 Tamże.

62 Tamże.

${ }^{63}$ Zob. np. tamże; A. Ligendza, Przewidywane efekty uczenia się $w$ grupach na katechezie, „Katecheta” 50(2006) nr 4, s. 74-77; M. Śnieżyński, Formy pracy grupowej w dialogu katechetycznym, „Katecheta” 58(2014) nr 10, s. 4-9.

64 Tamże.

${ }^{65}$ Zob. szczegółowe opisy tych metod np. w: M. Korgul, Dydaktyka dla katechetów, s. 159; S. Łabendowicz, Rozmowa w katechezie, s. 60-62; J. Szpet, Dydaktyka katechezy, s. 187-188.

${ }^{66}$ Zob. interesujące analizy na temat pogadanki i rozmowy: D. Klus-Stańska, Przerwanie szkolnego monologu znaczeń - bariery i szanse, w: Uczenie się jako przedsięwzięcie na cate życie, red. T. Bauman, Kraków 2005, s. 106-128.

${ }^{67}$ Tamże, s. 108. 
wanej nie sprzyja dialogowi edukacyjnemu. Przeciwnie umożliwia prowadzenie monologu znaczeń ${ }^{68}$.

Podobne sytuacje mają miejsce na płaszczyźnie wychowania. Zastosowanie rozmowy kierowanej i pogadanki w celu kształtowania społecznie pożądanych postaw świadczy o pozorowaniu dialogu ${ }^{69}$. Stąd też z perspektywy pedagogiki dialogu za istotne należy uznać tylko te propozycje katechetyków, w których zwraca się uwagę na ucznia (jego godność, indywidualność, prawo do własnego zdania) czy też na potrzebę słuchania jego różnych punktów widzenia oraz na rozwijanie umiejętności pracy nad sobą i uczenia się przez całe życie ${ }^{70}$. Integralnie $\mathrm{z}$ tym związane jest aktywne słuchanie i współdziałanie oparte na wzajemnym szacunku, tolerancji, otwartości ${ }^{71}$. Dobrze zatem, że w teorii nauczania religii wymienione kwestie zostały zauważone i ukazane jako znaczące dla integralnego wychowania uczniów, w którym ma miejsce wspólne wzrastanie wszystkich uczestników lekcji religii ${ }^{72}$.

\section{Zakończenie}

Pedagogika dialogu zawiera wielorakie inspiracje dotyczące spotkania osób, które przyczyniają się do lepszego rozumienia nie tylko otaczającego świata, ale także siebie innych. Można ją rozpatrywać zarówno w powiązaniu z procesami kształcenia, jak i wychowania. Podstawowe i znaczace dla teorii nauczania religii okazują się takie kategorie, jak: „relacja Ja-Ty”, spotkanie, zaangażowanie, odkrywanie i urzeczywistnianie swojego człowieczeństwa, kontakt interpersonalny. Pozwalają one określić proces wychowania jako wielostronną interakcję wychowawcy i wychowanka, w której wszyscy uczestnicy wychowują siebie wzajemnie. Procesom tym zawsze towarzyszy poszukiwanie prawdy i odkrywanie sensów oraz konstruowanie wiedzy. Dialog pełni tu funkcję narzędzia, za pomocą którego podmioty komunikują się ze sobą, dzieląc swoimi poglądami, przeżyciami, doświadczeniami, a przez to zbliżają do siebie. Obok dialogu rozumianego jako metoda, ważny jest również proces otwierania się uczestników zdarzeń edukacyjnych na siebie, dążenie do zrozumienia innych osób i zbliżenia się do nich oraz współdziałania. W nim bowiem urzeczywistnia się postawa dialogu nauczyciela i uczniów.

\footnotetext{
${ }^{68}$ D. Klus-Stańska, Przerwanie szkolnego monologu znaczeń..., s. 106-128.

${ }^{69}$ Tamże.

${ }^{70}$ Zob. np. J. Bagrowicz, Towarzyszyć wzrastaniu. Z dyskusji o metodach i środkach edukacji religijnej młodzieży, s. $114-118,230$ i nn; S. Łabendowicz, Wychowanie do dialogu w katechezie, s. 79-86; tenże, Metody ukierunkowane na dialog, s. 86-90; J. Tomczak, Wspomagajace i alternatywne sposoby porozumiewania się w katechezie, „Katecheza, Rodzina, Parafia i Szkoła” 2(2004), s. $81-89$.

${ }^{71}$ Tamże.

72 Tamże.
} 
Wymienione komponenty pedagogiki dialogu okazują się znaczące nie tylko dla teorii nauczania religii, a także dla praktyki. I chociaż katechetycy wiele uwagi poświęcają różnym odmianom metody i technik dialogu, to jednak nie pomniejszają znaczenia jego wymiaru wychowawczego. Świadczą o tym analizy dotyczące postawy nauczyciela religii jako wychowawcy, który nawiązuje i podtrzymuje wielorakie kontakty z uczniami. Aktywności tej zawsze towarzyszy świadomość powołania i posłannictwa. Stąd też słusznie propozycje katechetyków z zakresu pedagogiki dialogu nie ograniczają się do wyuczonych, rozwijanych na podstawie indywidualnych predyspozycji, umiejętności empatycznego i aktywnego słuchania, negocjowania znaczeń, poszanowania, lecz uwzględniają relację człowieka z Bogiem. W praktyce istotne jest łączenie tych dwóch wymiarów: ludzkiego i nadprzyrodzonego w celu autentycznego wspierania uczniów $\mathrm{w}$ integralnym rozwoju i urzeczywistnianiu człowieczeństwa.

Wobec powyższych ustaleń uzasadniona wydaje się weryfikacja empiryczna znaczenia pedagogiki dialogu $\mathrm{w}$ aktywności edukacyjnej nauczycieli religii. Pozwoli ona rozpoznać aktualny stan (zwłaszcza preferencje i kompetencje uczniów) oraz możliwości i ograniczenia związane $\mathrm{z}$ dialogiem w nauczaniu religii. Na tej podstawie można nie tylko określić znaczenie pedagogiki dialogu w nauczaniu religii, ale także opisać nowe wyzwania edukacyjne i zaproponować rozwiązania w zakresie formacji nauczycieli religii w celu rozwijania kompetencji komunikacyjnych i metodycznych.

\section{(Un)usual Significance of Dialogue Pedagogy in the Theory of Religious Education}

\section{Summary}

The theory of religious education holds a very important place in the Polish catechetics. It is continuously enriched with new issues, determined by the social and educational situation, that are significant from the point of view of practice. Some of them are integrally interwoven with pedagogy. Such issues include analyses related to the processes of communication between the religious education teacher and the students or to developing a dialogue approach in the participants of the religious education classes.

The religious education publications dealing with the above-mentioned problems do not directly include the category of dialogue pedagogy. However, several issues can be perceived as referring to the role of the dialogue understood as the approach and the method in teaching religious instruction. Additionally, the methods of conducting a dialogue between the religious education teacher and the students are repeatedly described. Their analysis leads to the conclusion that issues in the scope of dialogue pedagogy occupy an important place in the theory of religious instruction, since they refer to various dimensions of didactic and educating activity of the religious education instructor and the students. Nevertheless, they require detailed empirical research to determine the (un)usual significance of dialogue pedagogy in practice - in educational interactions between religious education teachers and students. 


\section{Keywords}

dialogue pedagogy, religious education, catechetics, religious education teacher

\section{Slowa kluczowe}

pedagogika dialogu, nauczanie religii, katechetyka, nauczyciel religii

\section{Bibliografia}

Al-Khamisy A., Edukacja właczajaca edukacja dialogu: w poszukiwaniu modelu edukacji dla ucznia ze specjalnymi potrzebami edukacyjnymi, Warszawa 2013.

Bagrowicz J., Towarzyszyć wzrastaniu. Z dyskusji o metodach i środkach edukacji religijnej młodzieży, Torun 2006.

Bagrowicz J., Stawać się bardziej człowiekiem. Z podstaw edukacji religijnej, Toruń 2008.

Bałoniak A., Od werbalizmu do komunikacji: refleksja nad środkami dydaktycznymi $w$ procesie nauczania, „Katecheta” 56(2012) nr 4, s. 67-72.

Bednarz E., Nauczyciel katecheta wobec współczesnych wyzwań dydaktycznych $i$ wychowawczych, „Rocznik Teologiczny” 5(2013) z. 1-2, s. 273-287.

Bibliografia katechetyczna 2001-2010, oprac. R. Czekalski, Warszawa 2012.

Chałupniak R., Asertywność i komunikacja katechety - w kierunku społecznej formacji katechetów, w: Dzisiejszy katecheta. Stan aktualny i wyzwania, red. J. Stala, Kraków 2002, s. 241-256.

Chałupniak R., Kostorz J., Wybrane zagadnienia z katechetyki, Opole 2002.

Czekalski R., Katecheza komunikacja wiary, Płock 2006.

Czekalski R., Katecheza komunikacja wiary. Studium z katechetyki fundamentalnej, Płock 2006.

Dialog w katechezie, red. S. Kulpaczyński, Lublin 1998.

Gadacz T., Wychowanie jako spotkanie osób, w: Człowiek - wychowanie - kultura, red. F. Adamski, Kraków 1993, s. 107-113.

Gogolik M., „Nauczycielu dobry...” Paradygmat nauczyciela religii w świetle rozmowy Jezusa Chrystusa z bogatym młodzieńcem, Poznań 2012.

Klus-Stańska D., Przerwanie szkolnego monologu znaczeń - bariery i szanse, w: Uczenie się jako przedsięwzięcie na całe życie, red. T. Bauman, Kraków 2005, s. 106-128.

Korgul M., Dydaktyka dla katechetów, Świdnica 2007.

Kostorz J., Ekumeniczny wymiar posoborowej katechezy w Polsce, Opole 2007.

Kreatorzy edukacyjnego dialogu, red. A. Karpińska, Białystok 2002.

Kujawiński J., Szkoła dialogu i samodzielnego uczenia się uczniów, Poznań 2006.

Kulpaczyński S., Dialog katechetów z Bogiem podstawa ich dialogu z katechizowanymi, w: Dialog w katechezie, red. S. Kulpaczyński, Lublin 1998, s. 71-82.

Kulpaczyński S., Jak uczyć modlitwy katechizowanych?, „Roczniki Teologiczne” 54(2007) z. 6, s. 157-173.

Ligendza A., Przewidywane efekty uczenia się w grupach na katechezie, „Katecheta” 50(2006) nr 4, s. 74-77. 
Łabendowicz S., Aktywizowanie uczniów poprzez zastosowanie pytań w katechezie, „Zeszyty Formacji Katechetów" 8(2008) nr 2, s. 78-82.

Łabendowicz S., Metody dialogowe i sytuacyjne na katechezie, „Zeszyty Formacji Katechetów" 10(2010) nr 3, s. 68-76.

Łabendowicz S., Metody dialogowe i sytuacyjne $w$ katechezie, „Zeszyty Formacji Katechetów" 10(2010) nr 3, s. 68-76.

Łabendowicz S., Metody ukierunkowane na dialog, „Zeszyty Formacji Katechetów” 12(2012) nr 1, s. 86-90.

Łabendowicz S., Rozmowa w katechezie, „Zeszyty Formacji Katechetów” 8(2008) nr 1, s. $60-62$.

Łabendowicz S., Wybrane metody aktywizujace w katechezie, „Zeszyty Formacji Katechetów" 13(2013) nr 2, s. 85-90.

Łabendowicz S., Wybrane propozycje metod $w$ katechezie, „Zeszyty Formacji Katechetów" 6(2006) nr 2, s. 73-76.

Łabendowicz S., Wychowanie do dialogu w katechezie, „Zeszyty Formacji Katechetów” 12(2012) nr 1, s. 79-86.

Łabendowicz S., Wychowanie do dialogu w katechezie, „Zeszyty Formacji Katechetów” 12(2012) nr 1, s. 79-86.

Łabendowicz S., Wychowanie do wspólnej modlitwy na katechezie, „Zeszyty Formacji Katechetów" 8(2008) nr 2, s. 73-77.

Łuszczak G., Od teorii stopni formalnych do teorii komunikacji $i$ dialogu $w$ dydaktyce szkolnej i katechetycznej, Kraków 2012.

Michałowski S.C., Spotkanie jako metoda bycia w pedagogice personalistycznej, w: Wychowanie na rozdrożu. Personalistyczna filozofia wychowania, red. F. Adamski, Kraków 1999, s. 129-143.

Milerski B., Pedagogika dialogu: filozoficzne inspiracje i perspektywy, „Paedagogia Christiana" 1/21(2008), s. 36-42.

Misiaszek K., W poszukiwaniu charakteru języka w katechezie, „Studia Pastoralne” 2 (2006), s. 95-103.

Murawska E., Od monologu do dialogu - refleksje o (nie)porozumieniu między nauczycielem a uczniem, „Edukacja” 2005 nr 2, s. 51-56.

Osewska E., Pluralizm metod stosowanych w katechezie, w: Dydaktyka katechezy, cz. II, red. J. Stala, Tarnów 2004, s. 157-299.

Pedagogika dialogu: dialog w teorii i praktyce edukacyjnej, red. E. Dąbrowy, D. Jankowska, Warszawa 2009.

Pedagogika dialogu: wokót pedagogii Janusza Korczaka, red. D. Jankowska, Warszawa 2014.

Przestrzeń i czas dialogu w edukacji, red. D. Waloszek, Kraków 2011.

Pytanie, dialog, wychowanie, red. J. Rutkowiak, Warszawa 1992.

Rutkowiak J., „Dialog bez arbitra” jako koncepcja relacji między nauczycielem a uczniem, „Ruch Pedagogiczny” 1984 nr 5-6, s. 120-128.

Rutkowiak J., Dialog pedagogiczny jako warunek możliwości rozumienia, „Ruch Pedagogiczny" 1989 nr 5-6, s. 58-51. 
Rutkowiak J., Stosowanie teorii pedagogicznej w praktyce a dialog edukacyjny, „Kwartalnik Pedagogiczny" 1986 nr 1, s. 47-58.

Stala J., Osewska E., Dyskutować, ale jak? „Tarnowskie Studia Teologiczne” 28(2009) z. 1, s. 39-50.

Studnicki P., Dialog edukacyjny w nauczaniu katechetycznym. Teoria a szkolna rzeczywistość, Kraków 2010.

Szpet J., Dydaktyka katechezy, Poznań 1999.

Szpet J., Kompetentny katecheta, „Katecheza, Rodzina, Parafia i Szkoła” 1(2003), s. 9-14.

Śnieżyński M., Droga do dialogu edukacyjnego, „Świat i Słowo” 2008 nr 2, s. 241-257.

Śnieżyński M., Formy pracy grupowej $w$ dialogu katechetycznym, „Katecheta” 58(2014) nr 10, s. 4-9.

Śnieżyński M., Od monologu do dialogu edukacyjnego, w: Wychowanie na rozdrożu. Personalistyczna filozofia wychowania, red. F. Adamski, Kraków 1999, s. 117-128.

Śnieżyński M., Rola i znaczenie pytań na lekcjach religii, „Katecheta” 58(2014) nr 4, s. 4-10.

Śnieżyński M., Sztuka dialogu, Kraków 2008.

Tarnowski J., Dialog podstawowa kategoria personalistycznej filozofii wychowania, w: Wychowanie na rozdrożu. Personalistyczna filozofia wychowania, red. F. Adamski, Kraków 1999, s. 185-186.

Tarnowski J., Jak wychowywać?, Warszawa 1993.

Tarnowski J., Pedagogika dialogu, w: Edukacja alternatywna. Dylematy teorii i praktyki, red. B. Śliwerski, Kraków 1992, s. 119-129.

Tomczak J., Wspomagajace i alternatywne sposoby porozumiewania się $w$ katechezie, „Katecheza, Rodzina, Parafia i Szkoła” 2(2004), s. 81-89.

Twardzicki B., Katechetyka formalna w stużbie wiary, Przemyśl 2001.

Walijewska U., Dialog w edukacji wczesnoszkolnej, http:/www.eid.edu.pl/archiwum/ 1999,97/czerwiec,150/dialog_w_edukacji_wczesnoszkolnej,865.html [dostęp: 23.04.2016].

Wychowanie do dialogu: $w$ poszukiwaniu modeli budowania relacji międzyludzkich, red. K. Jaworska, K. Wawrzynów, G. Sokołowski, Wrocław 2015.

Zellma A., Kompetencje nauczyciela religii jako perspektywa efektywności edukacyjnej, „Katecheta” 53(2009) nr 6, s. 3-12.

Zellma A., Profesjonalny rozwój nauczyciela religii, Olsztyn 2013. 